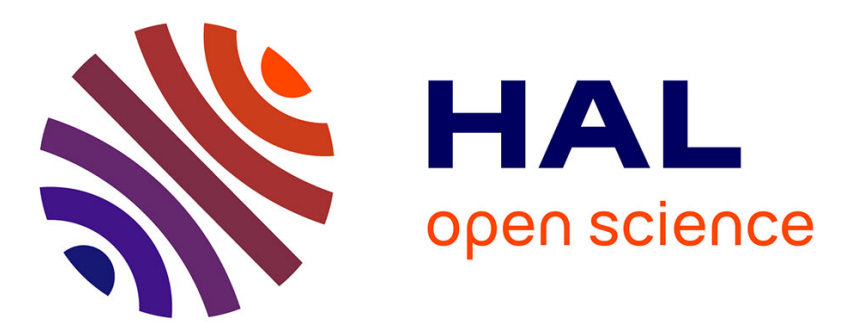

\title{
Concentration fluctuations in simple liquid alloys with atomic size mismatch
}

\author{
J.A. Alonso, J.M. López, N.H. March
}

\section{To cite this version:}

J.A. Alonso, J.M. López, N.H. March. Concentration fluctuations in simple liquid alloys with atomic size mismatch. Journal de Physique Lettres, 1982, 43 (12), pp.441-445. 10.1051/jphyslet:019820043012044100 . jpa-00232074

\section{HAL Id: jpa-00232074 https://hal.science/jpa-00232074}

Submitted on 1 Jan 1982

HAL is a multi-disciplinary open access archive for the deposit and dissemination of scientific research documents, whether they are published or not. The documents may come from teaching and research institutions in France or abroad, or from public or private research centers.
L'archive ouverte pluridisciplinaire HAL, est destinée au dépôt et à la diffusion de documents scientifiques de niveau recherche, publiés ou non, émanant des établissements d'enseignement et de recherche français ou étrangers, des laboratoires publics ou privés. 
Classification

Physics Abstracts

65.50

\title{
Concentration fluctuations in simple liquid alloys with atomic size mismatch
}

\author{
J. A. Alonso (*), J. M. López (*) and N. H. March (**) \\ $\left(^{*}\right)$ Departamento de Física Teórica, Universidad de Valladolid, Valladolid, Spain \\ $\left.{ }^{* *}\right)$ Theoretical Chemistry Department, University of Oxford, \\ 1 South Parks Road, Oxford OX1 3TG, England
}

(Reçu le 12 mars 1982, accepté le 19 avril 1982)

\begin{abstract}
Résumé. - L'expression de Flory pour l'énergie libre de mélange dans les alliages liquides binaires constitués d'atomes de dimensions différentes est modifiée par l'introduction de la dépendance en concentration de la chaleur de mélange, donnée par la théorie semi- empirique de Miedema. L'expression résultante est utilisée pour étudier les fluctuations de concentration des alliages liquides $\mathrm{Na} \mathrm{K}$ et $\mathrm{Na}$ Cs.

Abstract. - Flory's expression for the free energy of mixing of binary liquid alloys with atomic size mismatch is modified by introducing the concentration dependency of the heat of mixing given by the semiempirical theory of Miedema. The resulting expression is used to study the concentration fluctuations in liquid $\mathrm{Na} \mathrm{K}$ and $\mathrm{Na}$ Cs alloys.
\end{abstract}

The concentration fluctuations in binary liquid alloys with a small heat of mixing but with a sizeable atomic volume mismatch between the component metals cannot be explained by the Conformal Solution theory. To overcome this problem, Bhatia and March [1] have used Flory's theory $[2,3]$. In this theory, the free energy of mixing $\Delta G_{M}(c)$ of a liquid $A_{c} B_{1-c}$ alloy has the following form

$$
\Delta G_{\mathrm{M}}(c)=N K_{\mathrm{B}} T[c \ln \alpha+(1-c) \ln (1-\alpha)]+N W c(1-\alpha) .
$$

The first term is $(-T)$ times the entropy of mixing and the second term is the heat of mixing $\Delta H_{\mathrm{M}}(c) . N$ is the number of atoms in the alloy, $K_{\mathrm{B}}$ is the Boltzmann constant, $T$ is the temperature, $W$ is an interchange energy and $\alpha$ is the concentration by volume of species $A$

$$
\alpha=\frac{c V_{\mathbf{A}}}{c V_{\mathbf{A}}+(1-c) V_{\mathbf{B}}}
$$

where $V_{\mathrm{A}}$ and $V_{\mathrm{B}}$ are the partial molar volumes. The expression for the concentration fluctuations results from $[4,5]$

$$
\left\langle(\Delta c)^{2}\right\rangle=S_{c c}(0)=K_{\mathrm{B}} T /\left(\partial^{2} G_{\mathrm{M}}(c) / \partial c^{2}\right)_{T, P, N}
$$


where $S_{c c}(0)$ is the long wavelength limit of the concentration-concentration structure factor $S_{c c}(q)$. Using (1) in (3), Bhatia and March [1] found

$$
\left\langle(\Delta c)^{2}\right\rangle=\frac{c(1-c)}{1+c(1-c) \delta^{2}\left[1-\frac{2 W}{K_{\mathrm{B}} T} \frac{\beta \delta}{(\beta-1)^{3}}\right]}
$$

where $\beta=V_{\mathrm{A}} / V_{\mathrm{B}}$, and

$$
\delta=\frac{V_{\mathbf{A}}-V_{\mathbf{B}}}{c V_{\mathbf{A}}+(1-c) V_{\mathbf{B}}}
$$

This theory was used successfully to study the concentration fluctuations in liquid $\mathrm{Na}$ Cs alloys [1]. In this paper we are interested in simple alloys, that is, alloys with a small heat of mixing. In this case the excess volume of formation is generally near zero and we can approximate the partial molar volumes $V_{\mathrm{A}}, V_{\mathrm{B}}$ by the molar volumes $V_{\mathrm{A}}^{0}, V_{\mathrm{B}}^{0}$ of the pure metals.

We now recall that a semiempirical theory of the heat of mixing proposed by Miedema and coworkers $[6,7,8]$ gives the following concentration dependency for $\Delta H_{M}$

$$
\Delta H_{M}(c)=N W^{*} c\left(1-\alpha^{*}\right)
$$

where $\alpha^{*}$ is the atomic surface-area concentration for atoms $\mathrm{A}$, that is

$$
\alpha^{*}=\frac{c\left(V_{\mathrm{A}}^{0}\right)^{2 / 3}}{c\left(V_{\mathrm{A}}^{0}\right)^{2 / 3}+(1-c)\left(V_{\mathrm{B}}^{0}\right)^{2 / 3}} .
$$

The interchange energy $W^{*}$ is also given by the theory. This is in contrast to Flory's theory, where $W$ is a parameter to be fixed by the experiments. $W^{*}$ is a simple function of $\left(\phi_{\mathrm{A}}-\phi_{\mathrm{B}}\right)$ and $\left(n_{\mathrm{A}}^{1 / 3}-n_{\mathrm{B}}^{1 / 3}\right)$, where $\phi$ is the work function and $n$ is the electron density at the boundary of bulk atomic cells of the pure metal. Extensive tables of $W^{*}$ have been published [7]. According to Miedema, the heat of mixing is controlled by electronic interactions proportional to the total area of contact between dissimilar atomic cells. As a consequence, the atomic surface area concentration $\alpha^{*}$ appears in equation (6). In contrast, the atomic volume concentration $\alpha$ (strictly speaking, the partial molar volume concentration) appears in Flory's theory (Eq. (1)). For comparison, one should notice that in the Regular Solution theory

$$
\Delta H_{\mathbf{M}}(c)=N W c(1-c) .
$$

Since the theory of Miedema has been applied with considerable success during the past years to many problems related to the heat of formation of solid and liquid alloys it seemed worthwhile to study the consequences of an alternative form of the free energy of mixing, namely

$$
\Delta G_{\mathrm{M}}(c)=N K_{\mathrm{B}} T[c \ln \alpha+(1-c) \ln (1-\alpha)]+N W^{*} c\left(1-\alpha^{*}\right)
$$

in which Miedema's form for $\Delta H_{\mathrm{M}}(c)$ is combined with Flory's expression for the entropy of mixing. Using (9) in (3) we obtain after some algebra

$$
\left\langle(\Delta c)^{2}\right\rangle=\frac{c(1-c)}{1+c(1-c) \delta^{2}\left[1-\frac{2 W^{*}}{K_{\mathrm{B}} T} \frac{g(c)}{\delta^{2}}\right]}
$$


where

$$
\begin{aligned}
g(c) & =\frac{(c R+1)^{2}+R(c R+1)(1-2 c)-R^{2} c(1-c)}{(c R+1)^{3}} \\
R & =\left(V_{\mathbf{A}}^{0} / V_{\mathbf{B}}^{0}\right)^{2 / 3}-1 .
\end{aligned}
$$

The results of equations (4) and (10) will now be compared for liquid $\mathrm{Na} \mathrm{K}$ and $\mathrm{Na}$ Cs alloys. It has been emphasized by Bhatia and March [1] that Flory's theory is only valid for large volume ratios, say $V_{\mathrm{B}}^{0} / V_{\mathrm{A}}^{0} \geqslant 2$. In our case $V_{\mathrm{K}}^{0} / V_{\mathrm{Na}}^{0}=1.96$ and $V_{\mathrm{Cs}}^{0} / V_{\mathrm{Na}}^{0}=3.03$. The results for these two alloys are compared in figures 1 and 2, using the values of $W$ and $W^{*}$ giving the best fits

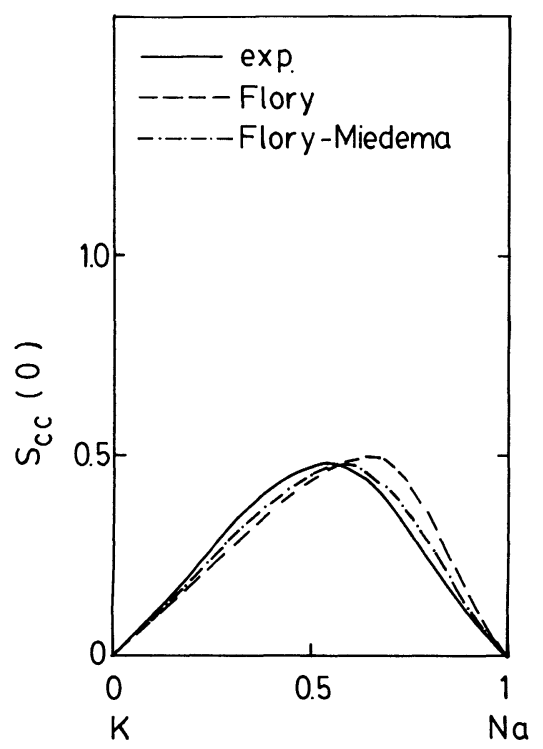

Fig. 1. - Concentration fluctuations in liquid $\mathrm{Na}_{c} \mathrm{~K}_{1-c}$ alloys. Experimental results are from reference [9]. Flory's results correspond to $W / K_{\mathrm{B}} T=0.9$. Flory-Miedema curve corresponds to $W^{*} / K_{\mathrm{B}} T=0.95$.

to the experimental results for $S_{c c}(0)$. This freedom is needed because the theoretical $W^{*}$ given by Miedema's theory [7] is usually not accurate enough for the present purposes. The figures show that the Flory-Miedema's theory is more successful than Flory's theory in $\mathrm{Na} \mathrm{K}$, whereas the opposite is true for $\mathrm{Na}$ Cs. The reason can be understood from the following argument : The heat of solution $\Delta H_{\mathrm{s}}$ can be obtained from the heat of mixing $\Delta H_{\mathrm{M}}(c)$ as

$$
\begin{aligned}
\Delta H_{\mathrm{s}}(\mathrm{A} \text { in } \mathrm{B}) & =\operatorname{Lim}_{c \rightarrow 0} \frac{\Delta H_{\mathrm{M}}(c)}{c(1-c)} \\
\Delta H_{\mathrm{s}}(\mathrm{B} \text { in } \mathrm{A}) & =\operatorname{Lim}_{c \rightarrow 1} \frac{\Delta H_{\mathrm{M}}(c)}{c(1-c)} .
\end{aligned}
$$

Thus, in Miedema's theory

$$
\frac{\Delta H_{\mathrm{s}}(\mathrm{B} \text { in } \mathrm{A})}{\Delta H_{\mathrm{s}}(\mathrm{A} \text { in } \mathrm{B})}=\left[\frac{V_{\mathrm{B}}^{0}}{V_{\mathrm{A}}^{0}}\right]^{2 / 3}
$$




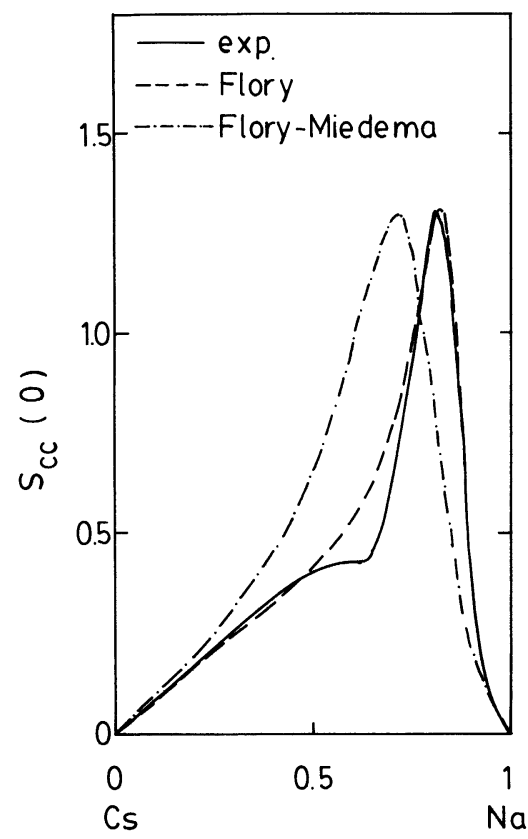

Fig. 2. - Concentration fluctuations in liquid $\mathrm{Na}_{c} \mathrm{Cs}_{1-c}$ alloys. Experimental results are from references [10] and [11]. Flory's curve corresponds to $W / K_{\mathrm{B}} T=1.14$. Flory-Miedema curve corresponds to

$$
W^{*} / K_{\mathrm{B}} T=1.49 \text {. }
$$

Table I. - Values of $\left(V_{\mathrm{B}}^{0} / V_{\mathrm{A}}^{0}\right),\left(V_{\mathrm{B}}^{0} / V_{\mathrm{A}}^{0}\right)^{2 / 3}$ and $\Delta H_{\mathrm{s}}(\mathrm{B}$ in $\mathrm{A}) / \Delta H_{\mathrm{s}}(\mathrm{A}$ in $\mathrm{B})$ for solid alloys (from Refs. [14] and [15]), and experimental values of $\Delta H_{\mathrm{s}}(\mathrm{B}$ in $\mathrm{A}) / \Delta H_{\mathrm{s}}(\mathrm{A}$ in $\mathrm{B})$ for liquid alloys (from Ref. [13]).

\begin{tabular}{|c|c|c|c|c|}
\hline $\begin{array}{l}\text { Alloy } \\
\text { (A B) }\end{array}$ & $\left(V_{\mathrm{B}}^{0} / V_{\mathrm{A}}^{0}\right)^{2 / 3}$ & $\left(V_{\mathrm{B}}^{0} / V_{\mathrm{A}}^{0}\right)$ & $\frac{\Delta H_{\mathrm{s}}(\mathrm{B} \text { in } \mathrm{A})}{\Delta H_{\mathrm{s}}(\mathrm{A} \text { in } \mathrm{B})}$ & $\frac{\Delta H_{\mathrm{s}}(\mathrm{B} \text { in } \mathrm{A})}{\Delta H_{\mathrm{s}}(\mathrm{A} \text { in } \mathrm{B})}$ \\
\hline- & - & - & - & - \\
\hline $\mathrm{Li} \mathrm{Na}$ & 1.45 & 1.74 & 1.56 & \\
\hline Li K & 2.18 & 3.23 & 2.52 & \\
\hline $\mathrm{Li} \mathrm{Rb}$ & 2.53 & 4.03 & 2.96 & \\
\hline $\mathrm{Li} \mathrm{Cs}$ & 3.04 & 5.31 & 3.76 & \\
\hline $\mathrm{Na} \mathrm{K}$ & 1.53 & 1.89 & 1.66 & 1.61 \\
\hline $\mathrm{Na} \mathrm{Rb}$ & 1.75 & 2.31 & 1.85 & 2.04 \\
\hline $\mathrm{NaCs}$ & 2.08 & 3.03 & 2.65 & 3.57 \\
\hline K Rb & 1.14 & 1.22 & 1.16 & 1.0 \\
\hline K Cs & 1.32 & 1.59 & 1.47 & 2.27 \\
\hline $\mathrm{Rb}$ Cs & 1.22 & 1.35 & 1.28 & 1.0 \\
\hline $\mathrm{Mg} \mathrm{Ba}$ & 1.95 & 2.72 & 1.99 & \\
\hline $\mathrm{Mg} \mathrm{Sr}$ & 1.80 & 2.42 & 1.95 & \\
\hline $\mathrm{Mg} \mathrm{Ca}$ & 1.52 & 1.87 & 1.65 & \\
\hline $\mathrm{Ca} \mathrm{Ba}$ & 1.28 & 1.45 & 1.53 & \\
\hline $\mathrm{Ca} \mathrm{Sr}$ & 1.19 & 1.29 & 1.40 & \\
\hline $\mathrm{Sr} \mathrm{Ba}$ & 1.08 & 1.13 & 1.0 & \\
\hline
\end{tabular}


whereas in Flory's theory

$$
\frac{\Delta H_{\mathrm{s}}(\mathrm{B} \text { in } \mathrm{A})}{\Delta H_{\mathrm{s}}(\mathrm{A} \text { in } \mathrm{B})}=\frac{V_{\mathrm{B}}^{0}}{V_{\mathrm{A}}^{0}} .
$$

The asymmetry of $\Delta H_{\mathrm{s}}$ is then higher in Flory's theory. The experimental values [12, 13] of $\left(V_{\mathrm{B}}^{0} / V_{\mathrm{A}}^{0}\right),\left(V_{\mathrm{B}}^{0} / V_{\mathrm{A}}^{0}\right)^{2 / 3}$ and $\Delta H_{\mathrm{s}}(\mathrm{B}$ in $\mathrm{A}) / \Delta H_{\mathrm{s}}(\mathrm{A}$ in $\mathrm{B})$ are $1.96,1.56$ and 1.61 respectively in $\mathrm{Na} \mathrm{K}$, and 3.03, 2.08 and 3.57 in $\mathrm{Na} \mathrm{Cs}$. Then, equation (15) does a better job for $\mathrm{Na} \mathrm{K}$ whereas equation (16) is more accurate for $\mathrm{Na}$ Cs. This is in agreement with the conclusion from figures 1 and 2. A more detailed comparison of equations (15) and (16) is provided in table I, where values of $\left(V_{\mathrm{B}}^{0} / V_{\mathrm{A}}^{0}\right),\left(V_{\mathrm{B}}^{0} / V_{\mathrm{A}}^{0}\right)^{2 / 3}$ and $\Delta H_{\mathrm{s}}(\mathrm{B}$ in $\mathrm{A}) / \Delta H_{\mathrm{s}}(\mathrm{A}$ in $\mathrm{B})$ are given for several simple homovalent alloys. The theoretical values of $\Delta H_{\mathrm{s}}(\mathrm{B}$ in $\mathrm{A}) / \Delta H_{\mathrm{s}}(\mathrm{A}$ in $\mathrm{B})$ were obtained $[14,15]$ using the Density Functional formalism [16]. The results of this table seem to favour equation (15). This conclusion is supported by the experimental results given in table 1 of reference [8], which correspond to liquid alloys with a heat of mixing substantially different from zero.

In summary, the combination of the Flory and the Miedema theories embodied in equation (9) can be helpful in studies of the concentration fluctuations in liquid alloys, in cases when atomic size mismatch is important. To close this work we mention that the authors have recently combined the Miedema theory with the Conformal Solution theory to study the concentration fluctuations in liquid alloys with small atomic size mismatch $[17,18]$.

Acknowledgments. - One of us (J. A. A.) thanks the British Council for support. This work was started when the same author visited the University of Oxford, sponsored by the A. L. I. S. Program.

\section{References}

[1] Bhatia, A. B. and March, N. H., J. Phys. F : Metal Phys. 5 (1975) 1100.

[2] Flory, P. J., J. Chem. Phys. 10 (1942) 51.

[3] Guggenheim, E. A., Mixtures (Oxford Univers. Press, Oxford) 1952.

[4] Bhatia, A. B. and Thornton, D. E., Phys. Rev. B 2 (1970) 3004.

[5] March, N. H. and Tosi, M. P., Atomic Dynamics in Liquids (MacMillan, London) 1976.

[6] Miedema, A. R., De Boer, F. R. and De Châtel, P. F., J. Phys. F : Metal Phys. 3 (1973) 1558.

[7] Miedema, A. R., De BoER, F. R. and BoOM, R., CALPHAD 1 (1977) 341.

[8] Miedema, A. R., De Boer, F. R. and Boom, R., Physica 103B (1981) 67.

[9] Hultgren, R. R., Desai, P. D., Hawkins, D. T., Gleiser, M. and Kelley, K. K., Selected Values of the Thermodynamic Properties of Binary Alloys (American Soc. for Metals, Ohio) 1973.

[10] IChikawa, K. and Thompson, J. C., J. Phys. F : Metal Phys. 4 (1974) L9.

[11] Ichikawa, K., Grandstaff, S. M. and Thompson, J. C., J. Chem. Phys. 61 (1974) 4059.

[12] Crawley, A. F., Int. Metall. Rev. 19 (1974) 32.

[13] Yokokawa, T. and KlepPa, O. J., J. Chem.'Phys. 10 (1964) 46.

[14] IÑiguez, M. P. and Alonso, J. A., J. Phys. F : Metal Phys. 11 (1981) 2045.

[15] González, D. J. and Alonso, J. A., Physica 112B (1982) 73.

[16] Hohenberg, P. and Kohn, W., Phys. Rev. 136 (1964) B864.

[17] Alonso, J. A. and March, N. H., Phys. Chem. Liquids 11 (1981) 341.

[18] Alonso, J. A. and March, N. H., Physica B (in press). 